\title{
NEW TECHNOLOGIES \\ Optimal subdivision of land in agrarian reform projects: an analysis using genetic algorithms
}

\author{
José Ambrósio Ferreira Netoํ, Edgard Carneiro dos Santos Junior ${ }^{2}$, Urbano \\ Fra Paleo ${ }^{3}$, David Miranda Barros ${ }^{3}$, Mayron César de Oliveira Moreira ${ }^{4}$ \\ ${ }^{1}$ CAPES, Brasil, LABORATE - Universidade de Santiago de Compostela, Rúa Benigno Ledo s/n (27002), \\ Lugo, España. \\ ${ }^{2}$ Universidade Federal de Viçosa, campus UFV (56571.000), Viçosa, Brasil. \\ ${ }^{3}$ LABORATE - Universidade de Santiago de Compostela, Rúa Benigno Ledo s/n (27002), Lugo, España. \\ ${ }^{4}$ Universidad de São Paulo, ICMC (13560-970) São Carlos, Brasil.
}

\begin{abstract}
J.A. Ferreira Neto, E.C. Santos Junior, U. Fra Paleo, D. Miranda Barros, and M.C.O. Moreira. 2011. Optimal subdivision of land in agrarian reform projects: an analysis using genetic algorithms. Cien. Inv. Agr. 38(2): 169-178. The objective of this manuscript is to develop a new procedure to achieve optimal land subdivision using genetic algorithms (GA). The genetic algorithm was tested in the rural settlement of Veredas, located in Minas Gerais, Brazil. This implementation was based on the land aptitude and its productivity index. The sequence of tests in the study was carried out in two areas with eight different agricultural aptitude classes, including one area of 391.88 ha subdivided into 12 lots and another of 404.1763 ha subdivided into 14 lots. The effectiveness of the method was measured using the shunting line standard value of a parceled area lot's productivity index. To evaluate each parameter, a sequence of 15 calculations was performed to record the best individual fitness average (MMI) found for each parameter variation. The best parameter combination found in testing and used to generate the new parceling with the GA was the following: 320 as the generation number, a population of 40 individuals, 0.8 mutation tax, and a 0.3 renewal tax. The solution generated rather homogeneous lots in terms of productive capacity.
\end{abstract}

Key words: Agrarian reform, genetic algorithm, rural settlement, spatial planning.

\section{Introduction}

The process of agrarian reform in Brazil is being carried out promptly and fragmentally, and it depends strongly on action from social and landless movements. Acting due to pressure from these movements, in general, effective actions from the Brazilian agrarian reform movement are being developed in projects of

Received August 20, 2009. Accepted May 19, 2011. Corresponding author: ambrosioufv@gmail.com rural settlements in government expropriated or purchased areas. Therefore, after a large estate is acquired via eminent domain, the state must prepare the property for new farmers by formal organization of the rural settlement. The constitution of rural settlements and the parceling stage for old large estates represents a challenge for the technicians who will implement it due to the difficulty of creating lots with similar productive capacity, among other problems. Such difficulties are related because one lot may include different types of soils that provide dif- 
ferent agricultural aptitudes. Therefore, in most instances, some families obtain more productivity from their lots than others. The system of agricultural land aptitude is an adaptation of soil classifications, developed by Ramalho Filho et al. (1978). He determined a hypothetical ideal for the development of agricultural practices, which incorporates synthesized attributes from parameters including nutrients, water, oxygen, erosion and mechanization. The ideal soil might not include deficiencies in nutrients, water and oxygen, erosion susceptibility, or mechanization difficulties. Land aptitude classes are determined by comparing the soil under evaluation and the hypothetically defined ideal soil, identifying deviations from the parameters described above. These agricultural aptitude classes are stratified in management levels A, $\mathrm{B}$ and $\mathrm{C}$ according to the technical, social and economic contexts of the farmers. Furthermore, the management levels are divided into six classes. Therefore, the determination of agricultural land aptitude results from the integration of these management levels and the degree of limitation that each land unit presents.

The best distribution (parceling) of an area of interest is intended to solve the problem studied, fitting each plot area and minimizing productive unevenness among lots due to the different types of soils. Thus, the settled families may develop their agricultural activity similarly in terms of productivity.

Considering the large number of parceling solutions, the use of precise methods is inviable. Thus, genetic algorithms (GAs) have become an alternative method for identifying the best solution for the problem. The use of algorithms is very common in processes of decision optimization, but works describing this tool used for land planning are scarce. Santos et al. (2005) and Santos et al. (2007) use GAs for selecting attributes for region classifications. Likewise, Tsuruta et al. (2001 and 2002) applied GAs in the selection of areas with better aptitude for agricultural development in Brazil. The use algorithms of simulated annealing for optimizing the reorganization of small plots in Galicia by Santé-Riveira et al. (2008) considered the different types of use and implications of the plot concentration.
The objective of this work was to contribute search solutions for parceling problems in agrarian reform projects. Therefore, we used GAs to design an optimal division tool for a large estate in the development of rural settlements in agrarian reform. The results from the fitness test of the algorithm input parameters are presented in this work, applied to the parceling of the Veredas settlement project (SP), and compared with the official parceling made by the Instituto Nacional de Colonizaçao e Reforma Agrária (INCRA), the department of the Brazilian government responsible for agrarian reform.

\section{Materials and methods}

\section{Characterization of the area under study}

The Veredas settlement project (SP) was created in 1998 in the municipality of Padre Paraíso, in the microregion of Jequitinhonha and the mesoregion of Vale do Jequitinhonha in northeast of Minas Gerais, Brazil (Figure 1). The settlement was an area of 1,200.778 ha, where 26 families live and develop their agricultural activity in individual lots. The area of the Veredas SP, according to the Köppen classification, has an Awa climate-tropical humid savanna climate (megathermal), with dry winters and rainy summers. A remarkably undulated and mountainous topography is predominant. The steep topography areas are associated with rocky outcrops in the highest zones, while the flattest topography borders strait meadows. In general, the soils are Haplic Cambisoil, RedYellow Argisoil, Litolic Neosil and Haplic Gleissoils, with restrictions in terms of the agricultural aptitudes described above due to low natural fertility, water deficit and susceptibility to erosion.

\section{Material}

The algorithm was coded in a Delphi 5.0 environment, and the tests were made by a low processing-capacity computer, which allows the tool to be usable on equipment that is easily accessible to any department. 


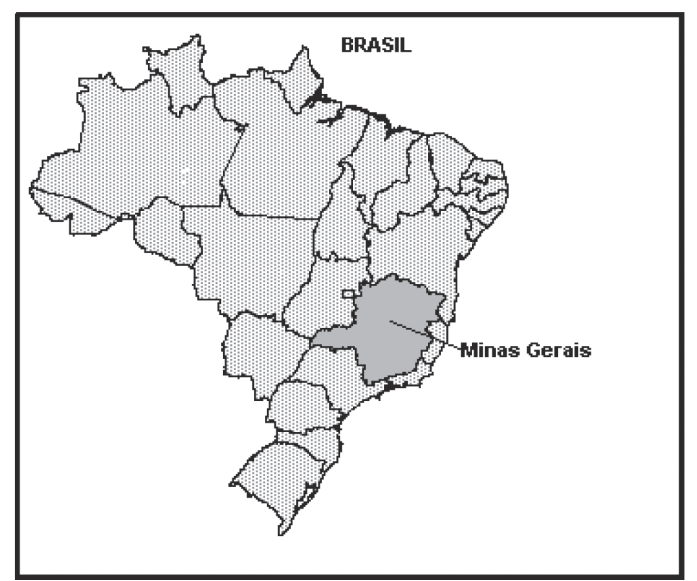

Figure 1. Geographical location of Minas Gerais, Brazil.

The agricultural soil aptitude plan from the Veredas SP area was used, on a 1:30,000 scale, elaborated by FUNARBE (2004) and by request from the INCRA, from which the new parceling proposal was made. The territorial organization plan elaborated and adopted by INCRA for analysis of the results was used, including 26 individual lots corresponding to production family units, two areas of legal reserve intended for environmental conservation and two areas for community use. The areas for collective use and environmental conservation were excluded from the parceling calculations with the genetic algorithm. The original plans using a vector model were converted to a raster model and then into text format for GA processing.

\section{Genetic algorithms}

According to Tanomaru (1995), most scientific problems may be formulated as optimization problems; the aim is to find the combination of factors affecting a problem and the mode fitness providing the best solution to the problem under study. The number of possible factor combinations represents a search space that may be restricted by a set of rules (restrictions). Essentially, from an optimization point of view, there are two approaches to use: accurate algorithms and heuristic algorithms. Accurate algorithms provide the advantage of an accurate solution to the problem; in other words, these methods call the optimal solution and are the best solution for all possibilities. However, from a computational resources perspective, this solution may take a long time. In general, optimization problems derive from a combinatory nature that exhausts equipment resources and makes relatively simple problems with small computers and a small volume of input data into unsolvable problems. Heuristic algorithms, although they do not represent an optimal solution to the problem, may provide solutions in a reasonable amount of time. GRASP, tabu search, simulated annealing, and genetic algorithms are among the most well known heuristic algorithms (Rodrigues, 2001).

Genetic algorithms (GAs) intend to employ a computer simulation using a natural evolution mechanism. In GAs, a population of feasible solutions evolves according to probabilistic operators elaborated from biological metaphors. Therefore, there is a tendency for individuals to get increasingly better as the evolutive process continues (Tanomaru, 1995). Natural evolution is based on intelligent search methods, that is, adaptive optimization mechanisms involving randomness associated with probabilistic concepts, although far from a purely random search. Generation after generation, the species individuals compete with each other for survival. The highest fitness individuals are more prone to transmitting their traits to the following generation. In other words, the more adapted organisms survive and reproduce in this environment. The introduction of natural mechanisms causing variation (mutations) in individuals and ensuring population diversity is also important.

\section{The basic process of a genetic algorithm}

The basic GA process follows the steps described in Figure 2. Each iteration of the algorithm is called a generation. A typical cycle comprises between 50 and 500 generations, although it may be higher. There will be one or more high fitness chromosomes in the population at the end of the cycle. It represents a very rapid and easily applicable procedure, which utilizes a low computational effort concentrated primarily at the selection stage and following the evaluation of the objective function. 
Variations on the basic model may be made to solve specific problems, including variations in the crossover, mutation and selection methods. Consecutive tests will help define optimal values for the input problem parameters. The crossover, mutation and selection processes make consecutive combinations and recombine the elements under analysis in search of more adapted individuals, following the principles of the natural election theory. According to Mitchell (1998), crossover is a random break followed by "chromosome" exchange and recombination, giving rise to a generation of new individuals. On the other hand, chromosomes are the physical traits of the analysis objectification. In this work, they are different aptitude classes of the area under parceling.

\section{Materials and methods}

The genetic algorithm adopted essentially follows the basic structure described above. The method has been modified for the area parceling problem, and specifically, a methodology for the generation of the initial solution cluster was developed. A population renewal procedure was also included: a specific number $\left(n_{\mathrm{r}}\right)$ of new random individuals was generated and introduced to each generation. This modification has been introduced to ensure a large diversity of the population elements, and thus, premature convergence of the solution cluster is avoided. Additionally, the crossover and mutation operators were included in the procedure of individual combination and added to the code adopted for the solution.

\section{Definition of the evaluation function}

The GA evaluation function, called the aptitude function or fitness, has been used for measuring individual capacity, and it may be determined in different forms. In this case, the objective was to search a mathematical function that allowed variation quantification of the productive capacity, in terms of the agricultural lot aptitude. Thus, the concept of a lot productivity index was included as a basis for the definition of the evaluation function. This index is calculated by summing the area in each agricultural aptitude class existing in the field, as defined previously, and multiplying by the productivity constant

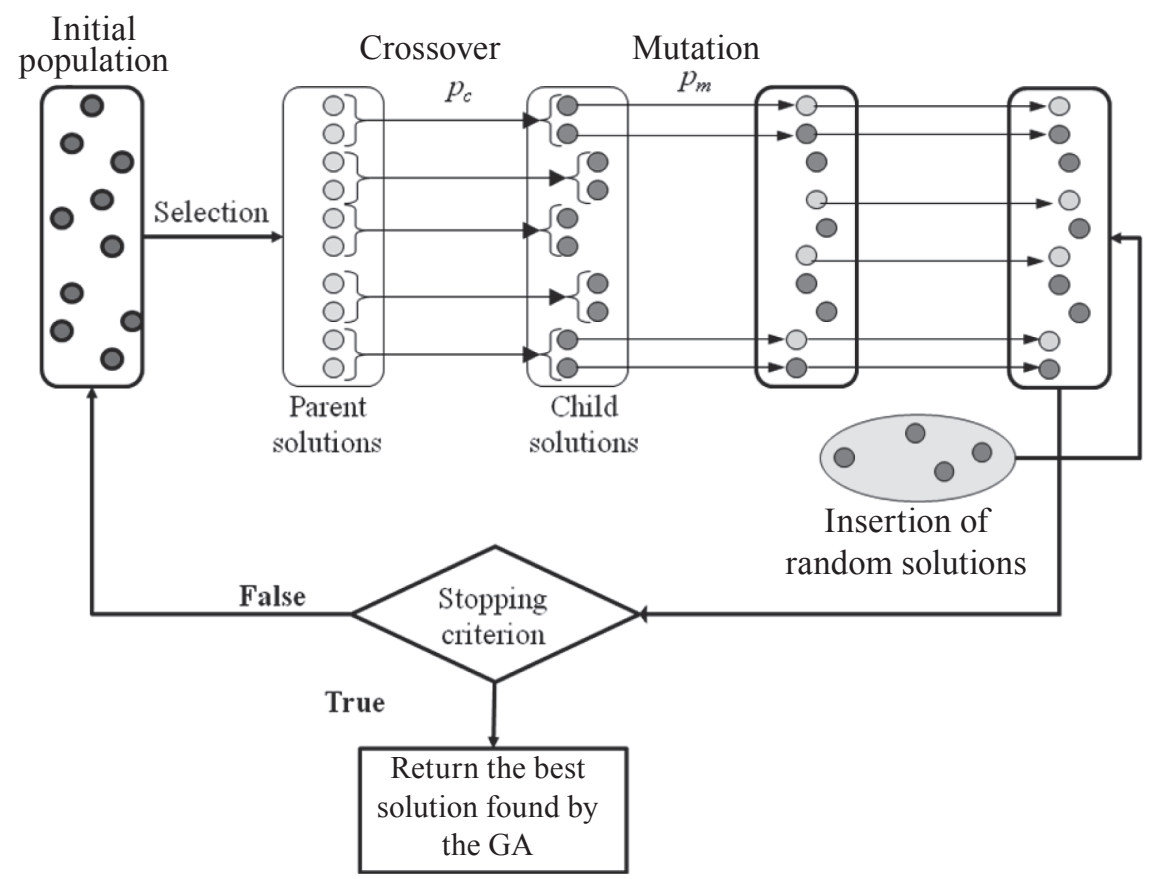

Figure 2. The basic process of a genetic algorithm. 
associated with the class (1). The productivity constant is defined according to the productive potential of the aptitude class. Therefore, the best quality classes, better management and lower use restrictions obtain higher weights than the classes with a lower potential for agricultural production. These classes have management levels demanding large capital and technology, with high legal or environmental use restrictions.

iPLote $_{i}=\sum_{j=1}^{n_{c}}\left(\right.$ ÁreaClasse $_{\mathrm{j}, \mathrm{i}} *$ ConstanteClasse $\left._{\mathrm{j}}\right)$

where:

iPLote $_{i}$ : The productivity index of lot $i$.

AreaClass $_{\mathrm{j}, \mathrm{i}}$ : Lot $\mathrm{i}$ area belonging to aptitude class $\mathrm{j}$.

ConstantClass: The productivity constant of the aptitude class $\mathrm{j}$.

$\mathrm{n}_{1}$ : Number of lots.

$\mathrm{n}_{\mathrm{c}}$ : Number of aptitude classes.

$\mathrm{i} \in\left\{1 . . \mathrm{n}_{1}\right\}$

There are some difficulties with attributing value to land according to the degree of agricultural soil aptitude, which generally represents a challenge for technicians and researchers. Therefore, the productivity constant has been defined to determine a compensation standard among the different productivity aptitude classes.

The indexes adopted were defined on an increasing scale according to the increase in soil use intensity to favor management levels A, which have better agricultural aptitude due to soil quality and few use restrictions and better represent the agricultural activity in the settle- ment projects with regard to the use of capital and production technologies and their respective indexes (Table 1). The values were defined according to the conditions of agricultural productivity from each class. Therefore, the best quality conditions and better aptitude conditions in terms of soil, water availability and topography had a higher score than other conditions suffering physical or legal order restrictions for agricultural use.

Once the values of the productivity lot index comprising the parceling solution of a property are defined, the solution fitness is calculated as the typical deviation of that value cluster (2).

$$
f(S)=\sigma\left(\text { iplote }_{1}, \ldots \text { iplote }_{n 1}\right)
$$

where:

$f(\mathrm{~S})$ : Solution S Fitness.

Finally the objective function of the optimization problem is defined (3). If $\mathrm{f}(\mathrm{S})$ is minimized, a solution $\mathrm{S}$ minimizing the statistical dispersion among lots is searched, and this is the solution that is closer to an equiproductive lot cluster.

$\operatorname{MIN} f(\mathrm{~S})$

\section{Results and discussion}

\section{Fitness of the algorithm parameters}

A test sequence was initially performed to define the best combination of GA parameters for the final parceling calculations. The test sequence was performed on two areas with 8

Table 1. A productivity index of the agricultural aptitude groups and use levels.

\begin{tabular}{lccccccc}
\hline & $\begin{array}{c}\text { Group 1 } \\
\text { Agricultural } \\
\text { A }\end{array}$ & $\begin{array}{c}\text { Group 2 } \\
\text { Agricultural } \\
\text { B }\end{array}$ & $\begin{array}{c}\text { Group 3 } \\
\text { Agricultural } \\
\text { C }\end{array}$ & $\begin{array}{c}\text { Group 4 } \\
\text { Planted pasture }\end{array}$ & $\begin{array}{c}\text { Group 5 } \\
\text { Forestry }\end{array}$ & $\begin{array}{c}\text { Group 5 } \\
\text { Natural pasture }\end{array}$ & $\begin{array}{c}\text { Group 6 } \\
\text { Without } \\
\text { agricultural use }\end{array}$ \\
\hline $\begin{array}{l}\text { Good aptitude } \\
\text { Regular } \\
\text { aptitude }\end{array}$ & 3,072 & 768 & 192 & 48 & 12 & 3 & 0 \\
$\begin{array}{l}\text { Limited } \\
\text { aptitude }\end{array}$ & 2,048 & 512 & 128 & 32 & 8 & 2 \\
\hline
\end{tabular}


agricultural aptitude classes, some presented by Ramalho Filho et al. (1978). An area of 391.88 ha was subdivided into 12 lots and another with 404.1763 ha subdivided into 14 lots, and values of reference for the aptitude classes were adopted and are presented in Table 1. The typical deviation of the productivity lot index of a parceling has been used as an effectiveness measure. A set of 15 repetitions were performed after the evaluation of each parameter, and the best individual fitness average (MMI) was measured for each variation of the parameter value.

The parameters evaluated were: generation number, population size, mutation tax and renewal tax. The values indicated in Table 1 were obtained during the implementation stage and were used as values of quality reference of the agricultural aptitude of the lots generated by GA, in terms of Good Aptitude, Regular Aptitude and Limited Aptitude. After each test, the value of the parameter was evaluated, which determined the other values according to the reference values obtained.

\section{Generation number}

The generation number corresponds to the maximum number of iterations of the algorithm in each cycle. As expected, the tests confirm that an increase in the generation number leads to an improvement in the final solution obtained. Nevertheless, this process has logarithmic performance; in other words, the degree to which an important increase in the generation number justifies the improved fitness obtained must be evaluated, while considering the additional time to reach a solution. It is important to remark that an increase in generation number increases the execution time of the program linearly.

\section{Population size}

An increase in the number of individuals is directly related to an increased search space, which supposes an increased probability of reaching better solutions. However, this increase diminishes the convergence speed. Thus, the increased population size must be associat- ed with the increase in the generation number to increase exploration time of the widened search space.

\section{Mutation tax}

The mutation operator is applied during the combination operation of the chromosomes associated with an occurrence probability, called the mutation tax. As mentioned before, an increase in the mutation tax causes an increase in the population variability, avoiding premature convergence to a minimum local value. Testing indicates that an improved fitness occurs as the mutation tax increases to values close to $80 \%(0.8)$.

\section{Renewal tax}

The renewal tax defines the percentage of the population that is replaced with each iteration. Similarly to the two previously evaluated parameters, population renewal introduces genetic variability, which increases the search space and prevents local minimum values. Testing suggests the use of a $30 \%$ renewal tax $(0.30)$.

The GA was tested as a tool for parceling calculations in two agrarian reform settlement projects, although the results presented in this work refer to Veredas SP. The parceling solution obtained divided the parcel into two adjacent areas, generating 12 lots in area 1 and 14 lots in area 2 , for a total of 26 lots, in agreement with the original number of lots proposed by the official parceling made by INCRA. The distribution of the areas is presented in Figure 3. The areas under study were parceled into two different areas that minimize the typical GA deviation using a lower number of lots generated and take advantage of watercourses as lot delimiters. The method versatility enables a total parceling in one occasion only or a partial parceling, which only decreases yield. The areas of legal environmental reserve and communitarian areas were excluded from the study because the main objective was the determination of a comparative quality table of individual lots between the original parceling and the proposed parceling by their agricultural aptitude. 


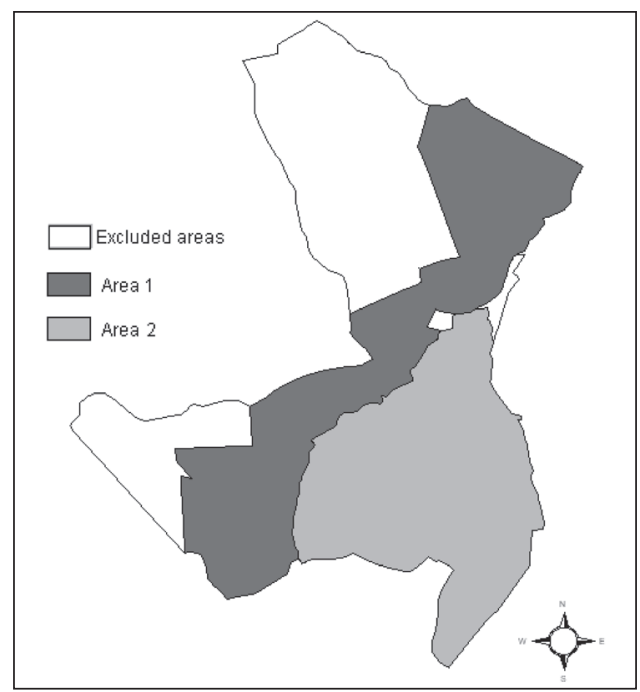

Figure 3. Study areas that will be parceled in PA Veredas.

Community areas were treated as non-productive areas, and therefore, they were assigned a productive index 0 in the evaluation function, which did not influence the quality calculation of the lots. However, a low value was assigned (1) to the productivity index in the areas of permanent conservation along the borders of watercourses in the calculation of the evaluation function because these areas have a wide legal use limitation due to fauna and flora conservation.

The parameter values used for generating the new parceling solution with GA were assigned according to the best individual results obtained in the tests, as previously described: 320 generations, a population of 40 individuals, a mutation tax of 0.8 and a renewal tax of 0.3 . Ten tests were made with these parameters, and the lowest result was extracted for each area under study. Subsequently, these areas were clustered, forming the parceling area of the Veredas settlement project.

The final result of the parceling obtained by the GA was a margin sectorized using a geographic information system (GIS). The .tif image was vectorized and converted to shape format using the data from the original settlement map, enabling it as a georeferencing. Figure 4 shows the distribution of lots generated by GA and the lots from the original parceling made by the INCRA (Instituto Nacional de Colonização e Reforma Agrária, Brazil).

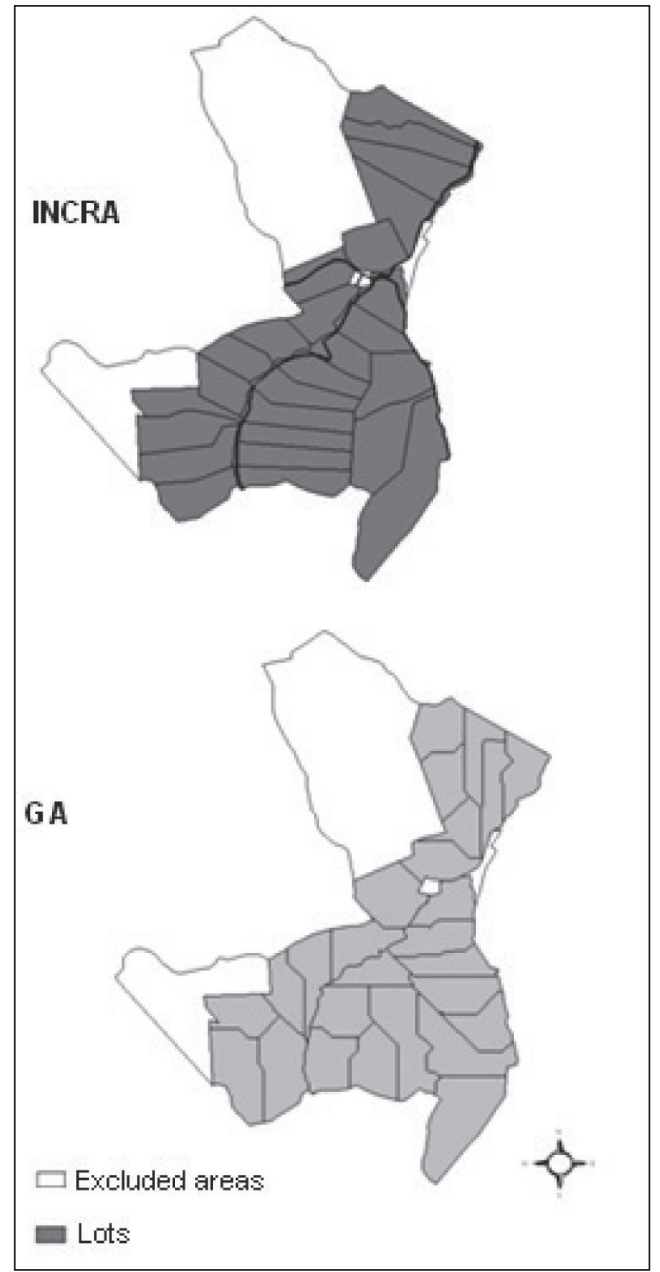

Figure 4. Current territorial organization of PA Veredas and the results of the genetic algorithms (GA).

Table 2 describes the fitness and the surface of each lot generated by GA as well as the fitness of the lots elaborated by the INCRA, the Brazilian organ responsible for agrarian reform. These results were obtained by subjecting the lots from the original parceling to the same calculation parameters as the quality evaluation function of the lots.

A comparison of the results obtained from the original parceling made by INCRA with the results from the GA, using the same parameters for calculation of the evaluation function developed for the new parceling, allows the following conclusions. 
Table 2. The fitness of the original lots generated by the INCRA and those generated by the genetic algorithms (GA).

\begin{tabular}{|c|c|c|c|c|c|}
\hline \multicolumn{3}{|c|}{ Parcels by INCRA } & \multicolumn{3}{|c|}{ Parcels from Genetic Algorithm } \\
\hline Lots & Fitness & Area (ha) & Lots & Fitness & Area (ha) \\
\hline 1 & $12,541.15$ & 82.6290 & 1 & $6,238.70$ & 59.5607 \\
\hline 2 & $6,600.76$ & 47.8812 & 2 & $6,354.69$ & 43.5362 \\
\hline 3 & $8,022.71$ & 35.4072 & 3 & $6,354.38$ & 25.8339 \\
\hline 4 & $3,855.30$ & 26.1228 & 4 & $6,266.39$ & 29.9470 \\
\hline 5 & $4,110.77$ & 27.9185 & 5 & $6,288.24$ & 24.3305 \\
\hline 6 & $5,196.66$ & 24.7380 & 6 & $6,340.25$ & 26.2788 \\
\hline 7 & $5,728.59$ & 28.9370 & 7 & $6,132.75$ & 22.4422 \\
\hline 8 & $5,166.10$ & 25.4812 & 8 & $6,265.05$ & 47.5927 \\
\hline 9 & $6,154.59$ & 24.6174 & 9 & $6,302.23$ & 32.4056 \\
\hline 10 & $5,912.69$ & 19.5049 & 10 & $6,192.39$ & 30.2761 \\
\hline 11 & $5,793.95$ & 24.3477 & 11 & $6,378.45$ & 28.5210 \\
\hline 12 & $6,230.93$ & 23.9735 & 12 & $6,249.52$ & 21.1811 \\
\hline 13 & $2,741.64$ & 28.0955 & 13 & $5,884.80$ & 43.5837 \\
\hline 14 & $4,524.95$ & 35.0780 & 14 & $5,780.43$ & 42.4696 \\
\hline 15 & $6,085.34$ & 33.9688 & 15 & $5,857.72$ & 27.0025 \\
\hline 16 & $5,929.03$ & 22.6903 & 16 & $5,892.93$ & 24.5573 \\
\hline 17 & $4,662.73$ & 21.3471 & 17 & $5,847.10$ & 27.4281 \\
\hline 18 & $4,622.21$ & 21.3454 & 18 & $5,833.50$ & 27.8281 \\
\hline 19 & $4,726.95$ & 21.4429 & 19 & $5,879.36$ & 37.6767 \\
\hline 20 & $3,951.81$ & 23.5676 & 20 & $5,920.49$ & 25.9334 \\
\hline 21 & $4,128.20$ & 26.4368 & 21 & $5,872.78$ & 20.4439 \\
\hline 22 & $7,115.94$ & 27.2989 & 22 & $5,857.91$ & 25.7652 \\
\hline 23 & $9,107.19$ & 38.3950 & 23 & $5,853.23$ & 28.0027 \\
\hline 24 & $9,731.76$ & 41.8064 & 24 & $5,961.81$ & 24.0811 \\
\hline 25 & $7,865.27$ & 32.5999 & 25 & $5,686.85$ & 23.1223 \\
\hline 26 & $6,734.09$ & 30.4118 & 26 & $5,751.40$ & 26.2814 \\
\hline
\end{tabular}

In the new parceling, the fitness values from each lot measuring quality based on the agricultural aptitude class are more homogeneous than the fitness of lots from the original parceling. This outcome shows the important quality differences existing among the lots from the original parceling made by INCRA, which may be observed when the fitness values between lots 1
$(12.541,25)$ and $13(2.741,64)$ are compared (Table 1). This comparison reveals that the productive capacity from lot 1 is five times higher than lot 13, which favors the highest productive capacity from that lot. This higher value from lot 1 , which comes from its fitness value, is more related to the lot size than the soil quality (it is approximately three times larger than lot 13). 
The fitness value of the lot may be more affected by size than agricultural aptitude class because in cases of low agricultural aptitude (low productivity index), the lot area will have a higher effective weight in the calculation of the evaluation function. Lot 1 is a good example of this situation for both parcels.

Only the area and agricultural aptitude variables in the fitness calculation were considered for parceling in this study. However, new calculation parameters may be added because the GA that was developed allows it. Minimum distance to the highway or closeness to watercourses are among these parameters. The value of the lot perimeter may also be included in the calculation of the aptitude function to minimize the probability of irregular or excessively elongated lots. This circumstance occurs commonly in algorithm iterations. It is noteworthy that in studying new crossing alternatives, this algorithm achieves higher efficiency of convergence speed and betterquality results are obtained when a very large number of lots is needed. Likewise, the aptitude function might be justified in situations with fewer aptitude classes, prioritizing the variation while minimizing in the lot area, instead of prioritizing the classes. It must be remarked that in the settlement projects presented, a number of occupants were already living in the area before the eminent domain by INCRA, such as farmers and "poseiros", and the parceling may include some lots with a previously defined locations where these workers were living and developing their activities. Thus, those lots must be included in the process of initial population generation leading to parceling. Finally, it is necessary to optimize values and weight assignments for the different agricultural aptitude classes (productivity index) and other variables, such as soil class, topography, or net water. Therefore, a balance between size and productive quality of the lots generated is achieved.

In some cases, the resolution of the parceling problem in settlement projects adopted by INCRA, mainly in projects without effective participation of the beneficiaries of this process, is enabling lot formation in which the productive capacity is hindering the occupation of these plots. Even when political, cultural or economic matters are excluded, the most difficult aspect of parceling rural settlements is linked to the attribution of value to the different agricultural aptitude classes associated with the variety of existing soils. This difficulty is recurring due to differences among the benefitting families and mainly due to the inability of the authorities to organize and finance productive projects specific to the environmental characteristics of the areas where settlement projects are carried out.

In regard to the use of new methodologies for parceling, it is necessary that technicians and researchers provide proposals reconciled with the heterogeneity and multifunctionality of family agriculture. The system of agricultural land aptitude is in contradiction with the traditional agricultural model because the characteristics of family agriculture previously were not considered, although various exploitation levels are included. A low use of capital and technology in exploitation (management A), for example, represents the reality of settlers.

As methodology, the developed GA reduces the parceling problem and enables territorial reorganization and parceling of rural settlements in agrarian reform projects, balancing the factors specified for the evaluation function. Therefore, the GA may be used as a supporting tool for obtaining a solution as well as debating with the benefitting families regarding different parceling options. The results obtained will depend on the degree of variable integration, such as the productivity index attributed to the agricultural land aptitude classes, topographical characteristics and vegetal cover, the access to surface water resources, existing ways and other variables that may be integrated into the decision making.

\section{Acknowledgements}

We are thankful for the financing from Fundación Carolina, Spain, for the development of this work in December 2008 and January 2009. 


\title{
Resumen
}

\begin{abstract}
J.A. Ferreira Neto, E.C. Santos Junior, U. Fra Paleo, D. Miranda Barros y M.C.O. Moreira. 2011. Ordenamiento territorial en proyectos de reforma agraria: un análisis utilizando algoritmos genéticos. Cien. Inv. Agr. 38(2): 169-178. El objetivo del presente artículo es desarrollar una nueva manera de realizar el ordenamiento territorial en proyectos de reforma agraria a través del empleo de un Algoritmo Genético (AG). El algoritmo genético fue testado en el Proyecto de Asentamiento Veredas, ubicado en Minas Gerais, Brasil, e implementado con base en el sistema de aptitud agrícola de las tierras y en la atribución de índices de productividad a las mismas. La secuencia de ensayos fue realizada sobre dos áreas conteniendo ocho tipos distintos de clases de aptitud agrícola, una de 391,88 ha, y parcelada en 12 lotes, y otra con 404,1763 ha parcelada en 14 lotes. Se ha utilizado como medida de eficacia el valor de la desviación estándar de los índices de productividad de los lotes de una parcelación. Cada parámetro evaluado fue realizado con una batería de 15 repeticiones, apuntándose la media del fitness del mejor individuo (MMI) encontrada para cada variación del valor del parámetro. La mejor combinación de parámetros encontrada en los ensayos, y utilizada para generar la nueva propuesta de parcelación por el AG, fueron las siguientes: número de generaciones igual a 320, tamaño de la población de 40 individuos, tasa de mutación de 0,8 y tasa de renovación de 0,3. La nueva propuesta generó lotes bastantes homogéneos, en términos de capacidad productiva.
\end{abstract}

Palabras clave: Algoritmos genéticos, asentamientos rurales, ordenamiento territorial, reforma agraria.

\section{References}

FUNARBE. 2004. Diagnóstico socioeconômico e ambiental e projeto final do PA Veredas. Fundação Arthur Bernardes (FUNARBE) e Instituto Nacional de Colonização e Reforma Agrária (INCRA). Viçosa, Belo Horizonte, Brasil. 124 pp.

Mitchell, M. 1998. An introduction to genetic algorithms, Cambridge: Massachusetts Institute of Technology MIT Press. 186 pp.

Ramalho Filho, A., E.G. Pereira, and K.J. Beek. 1978. Sistema de avaliação da aptidão agrícola das terras. Brasília, Empresa Brasileira de Pesquisa Agropecuária. 70 pp.

Rodrigues, F. L. 2001. Metaheurística e sistema de suporte à decisão no gerenciamento de recursos florestais. Tese (Doutorado em Manejo Florestal) - Universidade Federal de Viçosa. Viçosa, Brasil. 225 pp.

Santé-Riveira, I., M. Boullón-Magán, R. CrecenteMaseda, and D. Miranda-Barrós. 2008. Algorithm based on simulated annealing for land-use allocation. Journal Computers \& Geosciences 34: 259-268.

Santos, J.C., J.R. de F. Oliveira, L.V. Dutra. 2005. Uso de Algoritmos Genéticos na Seleção de
Atributos para Classificação de Regiões, VII Simpósio Brasileiro de Geoinformática, Campos do Jordão, Brasil. INPE - Instituto Nacional de Pesquisas Espaciais. p. 253-261.

Santos, J. C., Oliveira, J. R. F., Dutra, L. V., Santa'Ana, S. J. S., and Rennó, C. D. 2007. Seleção de atributos usando algoritmos genéticos para classificação de regiões, XIII Simpósio Brasileiro de Sensoriamento Remoto, Florianópolis, Brasil. INPE - Instituto Nacional de Pesquisas Espaciais. p. 6143-6150.

Tanomaru, J.M. 1995. Fundamentos e Aplicações de Algoritmos Genéticos. II Congresso Brasileiro de Redes Neurais, Curitiba, Brasil. p. 373-403.

Tsuruta, J. H., T. Hoshi, and Y. Sugai. 2001. Seleção de áreas adaptativas ao desenvolvimento agrícola, usando-se Algoritmos Genéticos, Brasília - DF: EMBRAPA. 48 pp.

Tsuruta, J. H., T. Hoshi, and Y. Sugai. 2002. Um estudo sobre seleção de áreas de desenvolvimento adaptável agrícola, usando algoritmos genéticos aplicados a muitas culturas, III Congresso da Associação Brasileira de Agroinformática (SBIAgro). Foz do Iguaçu, Brasil. 6 pp. 